\title{
Vulvar Ectopic Fibroadenoma
}

National Cancer Institute

\section{Source}

National Cancer Institute. Vulvar Ectopic Fibroadenoma. NCI Thesaurus. Code C128242.

A benign epithelial-stromal neoplasm that arises from the vulva and resembles the breast fibroadenoma. 